\title{
Wet and dry spells within particularly wet and dry summers in the South African summer rainfall region
}

\author{
Celia Cook $^{1}$, Chris J. C. Reason ${ }^{2, *}$, Bruce C. Hewitson ${ }^{1}$ \\ ${ }^{1}$ Climate Systems Analysis Group, Department of Environmental and Geographical Science, ${ }^{2}$ Department of Oceanography, \\ University of Cape Town, Private Bag, Rondebosch 7701, Cape Town, South Africa
}

\begin{abstract}
Atmospheric moisture transport over southern Africa and surrounding oceans is considered during wet and dry conditions over the South African summer rainfall region. Wet and dry synoptic spells within wet and dry austral summers are examined. A link between synoptic and seasonal timescales is investigated using seasonal statistics of wet and dry spells. Dry synoptic spells exhibit divergent moisture flux over South Africa, with inflow from the mid-latitude ocean regions to the south. Cyclonic features off the east coast may exist and attract moisture away from South Africa. For wet synoptic spells, there tends to be increased moisture flux from the tropical or subtropical southwest Indian Ocean (SWIO), either associated with ridging along the east coast or a deep low over the interior. Seasonal modulations of the intensity of the heat low over Angola/Namibia appear important for influencing early (OND) and late (JFM) summer rainfall over South Africa. This low may act as the tropical source for tropical temperate troughs and their associated cloudbands that are major synoptic rain-producing systems. Wet (dry) summers are often associated with a southward (northward) shift and strengthening (weakening) of the ITCZ over tropical southeastern Africa. Seasonal rainfall is found to be related to the distribution of wet and dry spells within the season, such that wetter seasons tend to have longer or more intense wet spells rather than a greater number of wet spells.
\end{abstract}

KEY WORDS: South African summer rainfall $\cdot$ Moisture transport · Rainfall variability $\cdot$ Interannual climate variability $\cdot$ Extreme events

\section{INTRODUCTION}

This study considers the patterns of atmospheric moisture transport over southern Africa and surrounding oceans during wet and dry conditions over South Africa. It looks particularly at the moisture transport and moisture divergence during wet and dry synoptic spells within anomalously wet and dry early and late summers (October-December [OND] and January-March [JFM]) from the past 2 decades. Lowlevel moisture originating from the southwest Indian Ocean (SWIO) and the tropical southeast Atlantic Ocean may be important, with the heat low that forms in summer over Angola and northern Namibia also affecting the moisture transport and synoptic rainfallproducing systems over subtropical southern Africa.
Given the influence of the Angola/Namibia low, and the fact that anomalously wet and dry seasons consist of a relatively small number of significant synoptic systems, the distributions of wet and dry spells of different durations and intensities are also examined.

The region has a relatively dry climate and a high degree of interannual rainfall variability, which impacts greatly on water resources, agriculture and rural communities. Recent examples include the devastating floods in northeast South Africa/southern Mozambique during February/March 2000 and the severe droughts of 1991/2, 2002/3, and 2003/4 over northern South Africa and surrounding areas.

Instrumental records show patterns of interannual and interdecadal rainfall variability associated with ElNiño-Southern Oscillation (ENSO) events and other 
modes (e.g. Lindesay 1988, Allan et al. 1996, Mason \& Jury 1997, Reason \& Rouault 2002). Links between regional sea-surface temperature (SST) anomalies and rainfall have also been investigated in both observational and modelling work (Walker 1990, Jury \& Pathack 1991, D'Abreton \& Tyson 1995, Mason 1995, Todd \& Washington 1998, Reason \& Mulenga 1999, Reason et al. 2000, Reason 2001, Tennant \& Hewitson 2002). Certain regions were found to be important for South African rainfall variability, particularly the SWIO and the western tropical Indian Ocean north of Madagascar (Walker 1990, D'Abreton \& Tyson 1995, Mason 1995, Reason \& Mulenga 1999).

A conceptual model of circulation patterns and SST anomalies during extended wet and dry spells (years to millennia) over eastern South Africa (Tyson 1986) suggests anomalous moisture flux from the northeast (southwest) during wet (dry) spells. Warm (cool) SSTs to the east and cool (warm) SSTs to the west of South Africa are expected in wet (dry) spells. This model suggests a tropical-temperate trough, with associated cloudband (Harrison 1984), occurs over the region during wet conditions and anticyclonic features persist during dry conditions. Tropical-temperate troughs and associated northwest-southeast cloudbands were found to dominate variability of November-March daily rainfall. Such systems were found to be fundamental for South African summer rainfall, accounting for 50 to $90 \%$ of rainfall over the central interior. This major mode of variability also appeared in an empirical orthogonal function (EOF) analysis of satellite-derived daily rainfall data (Todd \& Washington 1998). It showed a dipole pattern consisting of a tropicaltemperate trough region of enhanced convection alongside a similarly oriented band of suppressed convection.

D'Abreton \& Tyson $(1995,1996)$ investigated the potential moisture sources for South African summer rainfall and associated transport. Using ECMWF analyses for 1980-1989, these authors looked at wet and dry Octobers and Januaries, separating the moisture flux into divergent (velocity potential) and nondivergent (stream function) components. Their analysis suggested that early summer moisture transport was influenced more by mid-latitude circulation, while the tropical circulation dominated late summers. This relates to a change in synoptic weather systems over the region around December/January. Rain-bearing systems over South Africa tend to change from those with strong mid-latitude influence, e.g. cut off lows, to those where the tropical input dominates, e.g. tropical-temperate troughs, easterly waves and lows (Walker 1990, D'Abreton \& Tyson 1995).

For wet Octobers, D'Abreton \& Tyson $(1995,1996)$ found that moisture from the tropical southeast Atlantic and SWIO tended to converge north of South Africa, whereas in dry Octobers, the Atlantic inflow was negligible. The Indian-Ocean-sourced precipitation tended to be shifted north of South Africa by the mean circulation during dry Octobers. During wet Januaries, D'Abreton \& Tyson (1995) suggest an increased flow of moisture from the north due to an anomalous Hadley cell, associated with a southward shift of the InterTropical Convergence Zone (ITCZ), whereas reduced southeasterly moisture transport into the region from the SWIO appeared to characterise dry Januaries. However, a potential limitation of their study was that it assumed that October and January are always representative of the early and late summer respectively, and it neglected higher-frequency variability.

In addition to the neighbouring tropical oceans, potential moisture sources have also been found over tropical Africa (D'Abreton \& Lindesay 1993) and the Agulhas current region off the south coast (Jury et al. 1993). The importance of the latter region for summer rainfall has been demonstrated at synoptic, seasonal and interannual timescales (Crimp et al. 1998, Reason 1998, Rouault et al. 2002).

This paper builds on such studies to look at moisture transport under different synoptic and seasonal conditions. Unlike previous studies, moisture transport and divergence patterns are investigated during wet and dry spells on both synoptic and seasonal timescales. Given that the region is semi-arid, with some seasons made up of only a few significant rain events, it is important to consider this higher-frequency variability, as well as looking at the interannual variability of seasonal rainfall.

Section 3 deals with wet and dry pentad spells, looking at specific extreme events within wetter and drier than normal seasons. Moisture transport and divergence for individual wet and dry spells are shown and discussed. Other variables such as geopotential height, outgoing long-wave radiation (OLR) and SST are also used to gain a better understanding of the synoptic conditions during each spell. Anomalies in moisture flux and divergence during wet and dry early (OND) and late (JFM) summers are investigated using composites in Section 4. Section 5 relates seasonal rainfall to the statistics of wet and dry spell attributes within each season, using correlations.

\section{DATA AND METHODOLOGY}

Daily gridded South African rainfall data derived from daily station data from the Computing Centre for Water Research (CCWR; Pietermaritburg, South Africa) were used to identify wet and dry seasons and spells for investigation. These data are available up to 
December 1997. Reanalysis data from the National Center for Environmental Prediction (NCEP) Reanalysis Project (Kalnay et al. 1996) were used for the circulation. Anomalies of moisture flux and moisture divergence were derived from the NCEP data, while geopotential height, SST and OLR (Liebmann \& Smith 1996) anomalies were plotted directly from the CDC Website (http://www.cdc.noaa.gov/). The CCWR data have not been used in conjunction with NCEP Reanalyses for this kind of study for South Africa before. Analysis of these datasets also extends previous work, which has only been done on 1980-1989 data (D'Abreton \& Tyson 1995) or for individual case studies in 1980, 1981 and 1991 (D'Abreton \& Tyson 1996).

The moisture transport from the NCEP $6 \mathrm{~h}$ reanalysis data over southern Africa and the adjacent oceans is calculated as the product of specific humidity $(q)$ and winds $(u, v)$, giving a vector $(q u, q v)$ for 8 pressure levels from 1000 to $300 \mathrm{hPa}$. Similarly, moisture divergence was calculated from the divergence of $6 \mathrm{~h} q u$ and $q v$ values, and was then averaged to make daily and monthly data. Anomaly plots were calculated using a 20 yr monthly climatology (1980-1999), since the NCEP data is less reliable before 1979 due to a relative lack of observations over the Southern Hemisphere (Kalnay et al. 1996).

For simplicity, a time series of area-averaged rainfall over the region is created from the gridded data and used to assess the rainfall variability. The rectangular grid area $32-23^{\circ} \mathrm{S}, 24-32^{\circ} \mathrm{E}$ was found to enclose most of the South African summer rainfall region, from inspection of the $20 \mathrm{yr}$ JFM rainfall climatology, the climatological wettest season. Spatially averaged rainfall over the land within this region was used to identify wet and dry seasons and spells. The $20 \mathrm{yr}$ timeseries of normalised OND and JFM mean area-average rainfall (Fig. 1) shows substantial interannual variability. On this basis, the 2 wettest summers over the region are 1987/88 and 1995/96 and the driest are 1982/83 and 1991/92. These seasons were subsequently used to choose synoptic wet and dry spells for case studies. Seasonal composites used the wettest or driest 5 ONDs or JFMs, listed in Section 4. Spatial inhomogeneity in the rainfall distribution over the summer rainfall region means that choice of region will determine the dates of wet and dry spells. However, the rectangular area defined is deemed adequate for the stated objectives, and it is indicated on the plots of rainfall, moisture flux and moisture divergence (Figs. 2-13).

Wet and dry spells were restricted to $5 \mathrm{~d}$ periods (pentads), in order to isolate synoptic scale systems

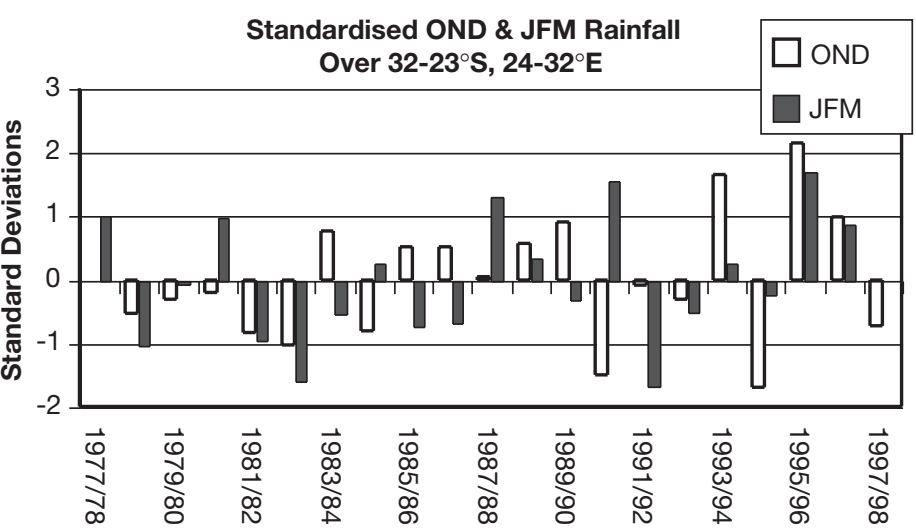

Fig. 1. Normalised interannual rainfall variability for early and late summers (OND and JFM)

such as tropical temperate troughs, ridging highs and easterly waves, which are important for South African summer rainfall. Key wet and dry spells were identified by inspecting the daily time-series plots of areaaverage rainfall data for each of the OND and JFM seasons chosen. One wet and one dry spell were chosen for each season, often the wettest or driest. Altogether 8 wet and 8 dry spells were chosen (Table 1 shows the dates). These were compared, using means and anomalies of moisture transport and moisture divergence calculated from the NCEP Reanalysis data. Other NCEP variables, such as geopotential height, OLR and SST were inspected to gain a better understanding of the synoptic conditions during each spell.

Analysis of composites, presented in Section 4, deals with the OND and JFM seasons separately, because of the difference between OND and JFM rainfall variability (Fig. 1) and the change in predominant rainfall systems (Walker 1990, D'Abreton \& Tyson 1995). The moisture flux and circulation patterns associated with anomalously wet and dry OND and JFM seasons were investigated. Since such seasons tend to be defined by several extreme wet and dry spells, Section 3 considers a few specific examples of these spells.

Table 1. Dates for the dry and wet spells

\begin{tabular}{|ll|}
\hline Dry spell dates & Wet spell dates \\
\hline $01-05$ Oct 1982 & 29 Oct-02 Nov 1982 \\
15-19 Feb 1983 & 12-16 Jan 1983 \\
03-07 Oct 1987 & 25-29 Sep 1987 \\
26-30 Jan 1988 194 Feb 1988 \\
03-07 Oct 1991 & 20-24 Oct 1991 \\
07-11 Mar 1992 & 19-20 Feb 1992 \\
24-28 Oct 1995 & 17-21 Nov 1995 \\
05-09 Mar 1996 & 23-27 Jan 1996 \\
\hline
\end{tabular}


Table 2. Common characteristics of dry and wet spells

\begin{tabular}{|c|c|c|}
\hline Variable & Dry spells & Wet spells \\
\hline \multirow[t]{2}{*}{$\begin{array}{l}850 \mathrm{hPa} \text { geopotential } \\
\text { height anomaly }\end{array}$} & $\begin{array}{l}\text { Negative away from region: } \\
\text { off east coast }\end{array}$ & $\begin{array}{l}\text { Positive to south, with ridge over } \\
\text { east coast }\end{array}$ \\
\hline & Or large-scale positive & Or strong negative over South Africa \\
\hline $\begin{array}{l}\text { Moisture flux anomaly and inflow } \\
\text { direction }\end{array}$ & $\begin{array}{l}\text { Weak anticyclonic } \\
\text { S/SW }\end{array}$ & $\begin{array}{l}\text { Cyclonic in N } \\
\text { Anticyclonic SE E/NE/SE }\end{array}$ \\
\hline Moisture divergence & $\begin{array}{l}\text { Large area of divergence over } \\
\text { or near the region }\end{array}$ & $\begin{array}{l}\text { Surrounding region or S or E of } \\
\text { region generally }\end{array}$ \\
\hline Moisture convergence & Outside or at the N/E edges of the region & Over $\mathrm{N}, \mathrm{W}$ or NW of region \\
\hline OLR anomaly & Positive-suppressed convection & Negative-enhanced convection \\
\hline
\end{tabular}

\section{WET AND DRY SPELLS: 5-DAY MEANS AND ANOMALIES}

The chosen wet and dry $5 \mathrm{~d}$ spells are described below in terms of their characteristics of circulation and moisture flux patterns. Two of the extreme dry spells (Figs. $2 \& 3$ ) and 3 of the extreme wet spells (Figs. 4-6) are shown as examples. Two main synoptic rainfall patterns were noted for wet spells, namely, a tropical temperate trough with associated cloudband feature and an easterly low respectively; an example of each is discussed. Moisture transport and moisture divergence at $850 \mathrm{hPa}$ are shown for each spell, since that level is close to the surface over much of the land; rainfall is also shown for wet spells. Other variables, such as geopotential heights, OLR, vertical motion and monthly SSTs, were also examined to obtain a better understanding of the circulation and synoptic conditions during the spells. Common features of these wet and dry spells are summarised in Table 2.

\subsection{Specific dry spells}

1-5 October 1982 (Fig. 2) was a very dry period with only a few small areas of rainfall. A positive $850 \mathrm{hPa}$ geopotential height anomaly, reflected in the moisture transport anomaly, was located over South Africa, whereas an upper level ( $300 \mathrm{hPa})$ high existed south of South Africa and a low existed over Madagascar and the adjacent Indian Ocean. Anticyclonic and divergent anomalies were present over southern Angola and northern Namibia (Fig. 2), weakening the tropical low there, which often acts as a source for tropical temperate troughs. Monthly SST anomalies were warm in the tropical Indian Ocean and west of South Africa, and cold south of South Africa and around Madagascar, a pattern that is unfavourable for rain over eastern South Africa (Walker 1990, Mason 1995, Reason \& Mulenga 1999). These SST and height anomalies are also con- sistent with the patterns expected for the austral spring of a strong El-Niño event (Reason et al. 2000). $850 \mathrm{hPa}$ moisture transport anomalies (Fig. 2a) show weakly enhanced easterly flow from the SWIO, but it diverged over the summer rainfall region (Fig. 2). A positive OLR anomaly (not shown), indicating decreased convection, extended over most of southern Africa poleward of $15^{\circ} \mathrm{S}$, and across the SWIO. Negative OLR anomalies occur over northern Madagascar and northern Mozambique (enhanced convection), where there is a region of relative moisture convergence (Fig. 2b).

The dry spell of 26-30 January 1988 occurred during a very wet JFM season (Fig. 3), and exhibited light but widespread rainfall, with considerably more just outside the region along the south coast (not shown). A cyclonic feature in the Mozambique Channel dominates the $850 \mathrm{hPa}$ moisture transport anomaly plot (Fig. 3a) and draws off moisture flowing into South Africa from the SWIO, while an anticyclonic anomaly of similar extent lies southeast of Madagascar. Weakening of the low in the eastern Angola/Namibia region is also apparent. Relative low-level divergence occurs over the north and east of the summer rainfall region (Fig. 3b) as well as over Botswana and southern Mozambique, while relative convergence lies further north and over southern Madagascar. Weak anomalous convergence over central South Africa is associated with a small easterly flux of moisture along the south coast. Positive upper level geopotential height anomalies (not shown) lie to the east and west and negative anomalies to the south of the country. Warm SST anomalies cover most of the western Indian Ocean, and there are cool anomalies south of South Africa, again unfavourable for summer rainfall over South Africa (Reason \& Mulenga 1999). Positive OLR anomalies over South Africa and neighbouring countries and negative over the Mozambique Channel imply a shift of convective activity away from South Africa, i.e. to lie preferentially over Madagascar and northern Mozambique. 

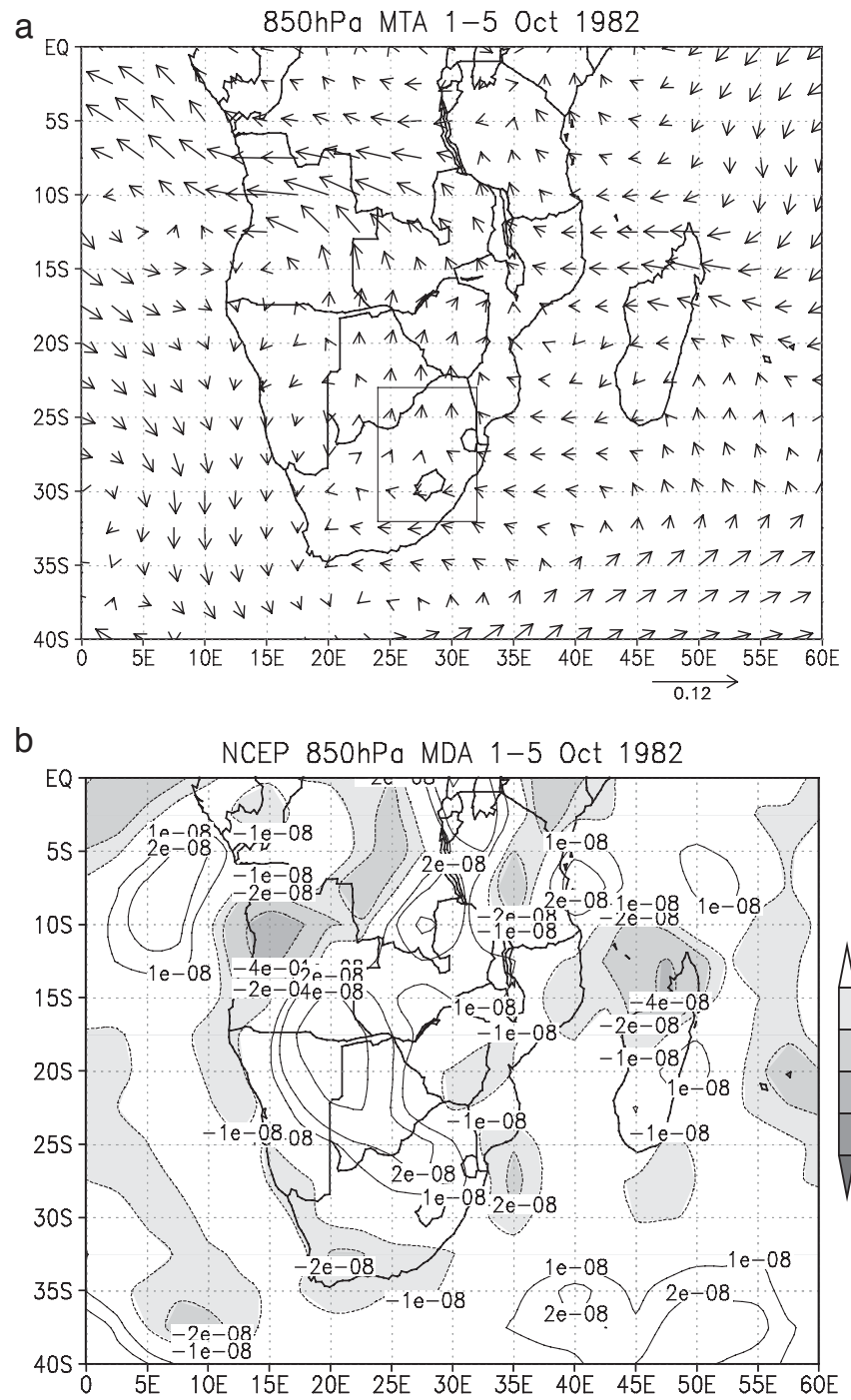

Fig. 2. Dry spell 1-5 October $1982850 \mathrm{hPa}$ anomalies: (a) moisture transport (scale vector size $0.12 \mathrm{~kg} \mathrm{~kg}^{-1} \mathrm{~ms}^{-1}$ ), (b) moisture divergence (negative anomalies shaded, contours are plotted at levels of $\pm 1 \times 10^{-8}, 2 \times 10^{-8}, 4 \times 10^{-8} \mathrm{~kg}$ $\mathrm{kg}^{-1} \mathrm{~s}^{-1}$ )

\subsection{Specific wet spells}

During the wet spell of 20-24 February 1988 (Fig. 4), rainfall covered a NW/SE band typical of a tropical-temperate trough, which can be seen in the daily sequence of $850 \mathrm{hPa}$ geopotential height plots (not shown). Some rainfall also fell over northeastern South Africa (Fig. 4a) and is associated with orographic uplift of the easterly flow from the Mozambique Channel. Anomalous negative OLR (not shown), indicating enhanced convection, coincides with this rainfall pattern. An upper-level, positive geopotential height anomaly is located over the SWIO with a ridge over the east coast, and a trough over the west coast of South Africa. A large a

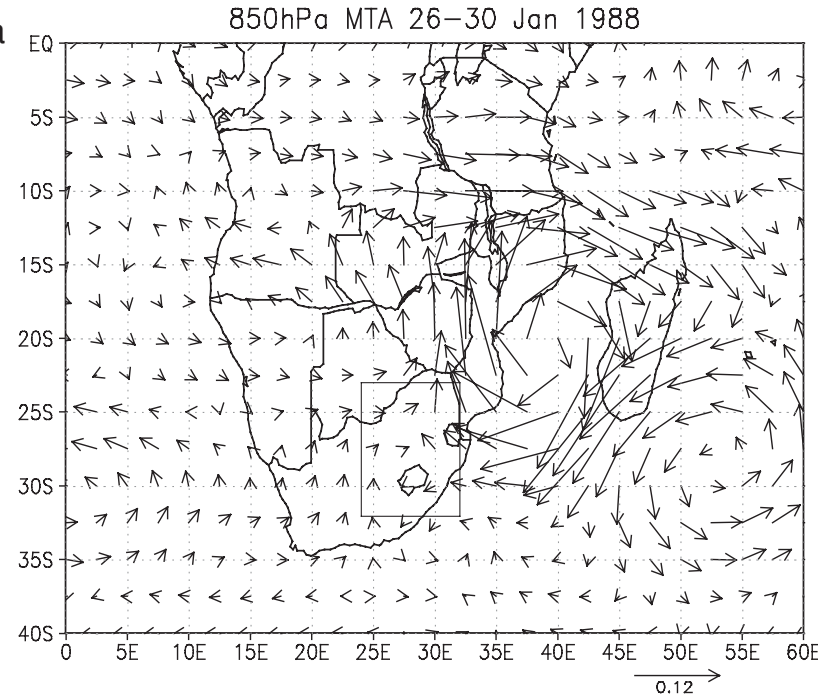

b

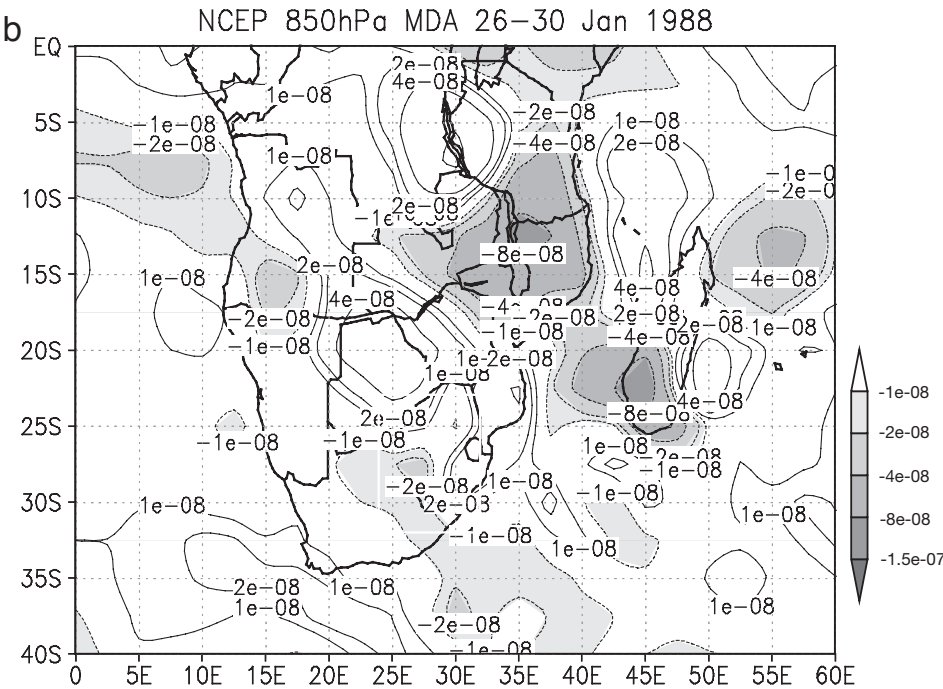

Fig. 3. Dry spell 26-30 January $1988850 \mathrm{hPa}$ anomalies: (a) moisture transport (scale vector size $0.12 \mathrm{~kg} \mathrm{~kg}^{-1} \mathrm{~ms}^{-1}$ ), (b) moisture divergence (negative anomalies shaded, contours are plotted at levels of $\pm 1 \times 10^{-8}, 2 \times 10^{-8}, 4 \times 10^{-8} \mathrm{~kg}$ $\mathrm{kg}^{-1} \mathrm{~s}^{-1}$ )

anticyclonic moisture transport anomaly existed southsoutheast of Madagascar at $850 \mathrm{hPa}$ and a cyclonic anomaly over Botswana (Fig. 4b), suggesting a relative southeastward shift of the Angola low. Both these anomalies contribute to an anomalous northeasterly flow of warm moist tropical air into the South African region from the Mozambique Channel, converging over the northern half of the region and further north. A band of relative convergence at $850 \mathrm{hPa}$ (Fig. 4c) stretches from Namibia across northern South Africa to Madagascar and is strongest over Botswana near the source of this cloudband. SST anomalies were warm in the southeast Atlantic and the SWIO, a pattern favourable for increased South African rainfall (Reason 1998). 

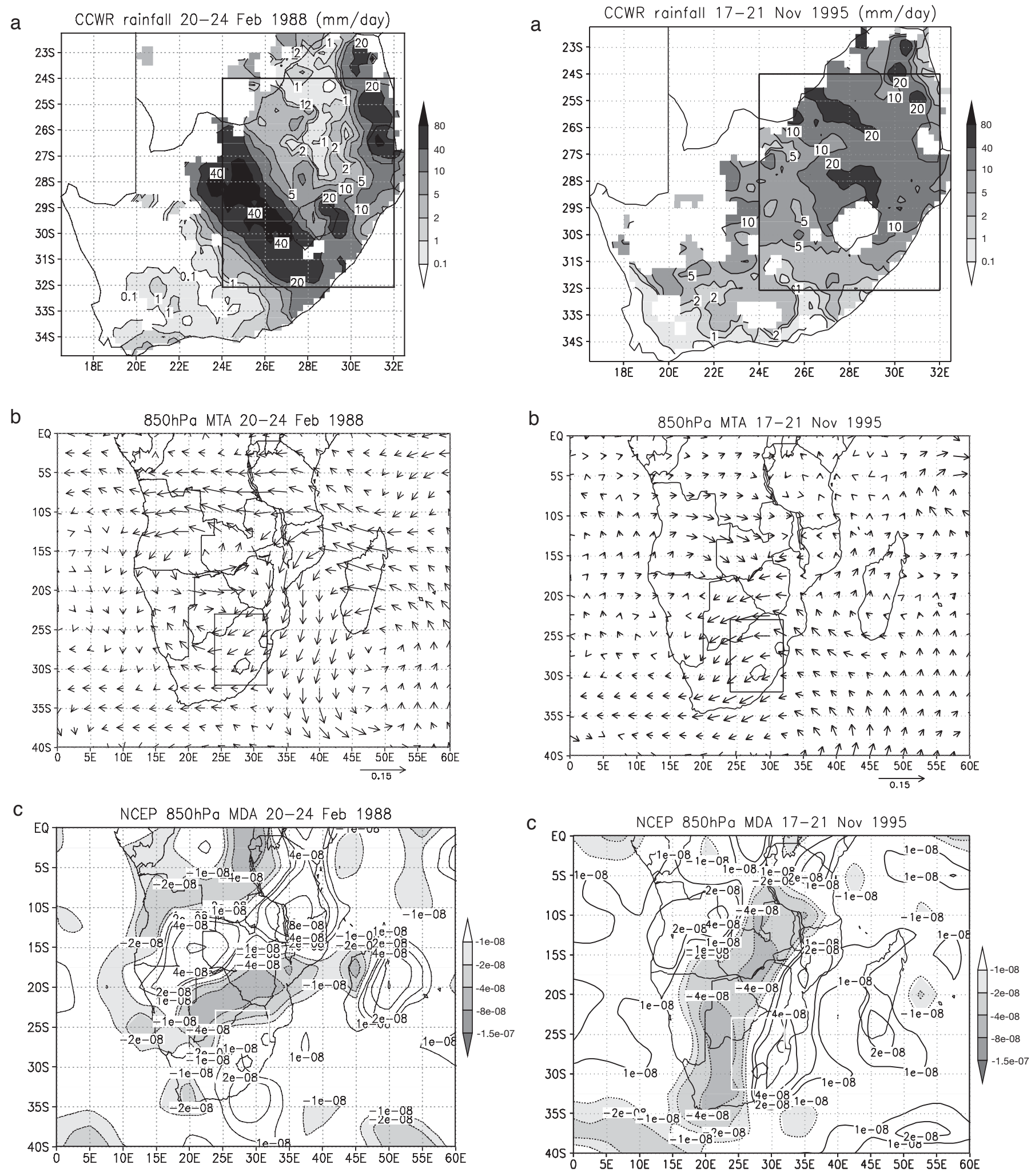

Fig. 4. Wet spell 20-24 February 1988: (a) rainfall (contour levels $0.1,1,2,5,10,20,40,80 \mathrm{~mm} \mathrm{~d}^{-1}$ ), (b) $850 \mathrm{hPa}$ moisture transport anomaly (MTA) (scale vector size $0.15 \mathrm{~kg} \mathrm{~kg}^{-1} \mathrm{~ms}^{-1}$ ), (c) $850 \mathrm{hPa}$ moisture divergence anomaly (MDA) (negative anomalies shaded, contours are plotted at levels of $\pm 1 \times 10^{-8}$, $2 \times 10^{-8}, 4 \times 10^{-8}, 8 \times 10^{-8}, 1.5 \times 10^{-7} \mathrm{~kg} \mathrm{~kg}^{-1} \mathrm{~s}^{-1}$ )

Fig. 5. Wet spell 17-21 November 1995: (a) rainfall (contour levels $0.1,1,2,5,10,20,40,80 \mathrm{~mm} \mathrm{~d}^{-1}$ ), (b) $850 \mathrm{hPa}$ MTA (scale vector size $0.15 \mathrm{~kg} \mathrm{~kg}^{-1} \mathrm{~ms}^{-1}$ ), (c) $850 \mathrm{hPa}$ MDA (negative anomalies shaded, contours are plotted at levels of $\pm 1 \times$ $10^{-8}, 2 \times 10^{-8}, 4 \times 10^{-8} \mathrm{~kg} \mathrm{~kg}^{-1} \mathrm{~s}^{-1}$ ) 
The wet spell 17-21 November 1995 (Fig. 5) shows a widespread rainfall pattern, with largest falls in the northwest of the summer rainfall region (Fig. 5a). A widespread negative OLR anomaly over northern South Africa matches this rainfall distribution. At $850 \mathrm{hPa}$, a weak positive geopotential height anomaly existed south of the country (not shown), with a ridge over the east coast and a cyclonic anomaly over Angola/Botswana/Namibia, reflecting a deepened Angola low. This circulation pattern is characteristic of an easterly low with associated widespread rains. Anticyclonic conditions at upper levels over southeastern Africa promote uplift and convection within the easterly low, whereas a cyclonic anomaly over the west coast leads to northwesterly flow of cool, dry air ahead of the system, further promoting instability over the summer rainfall region. Monthly SSTs showed a warm anomaly over the SWIO, favourable for rain (Reason \& Mulenga 1999). Consistent with the geopotential height patterns, $850 \mathrm{hPa}$ moisture transport anomalies (Fig. 5b) showed increased inflow from the SWIO into the region. This flow increases over the land, diverging near the east coast (Fig. 5c) with a band of strong relative convergence over central and western South Africa, Botswana and Zambia.

\subsection{Summary of synoptic dry-spell characteristics}

The moisture flux anomalies in the 8 synoptic dry spells display 3 characteristic circulation patterns. One obvious pattern that 3 of the dry spells exhibit is the presence of a cyclonic anomaly in or near the Mozambique Channel, where southeasterly moisture flow into South Africa is drawn away again to the northeast towards the offshore cyclonic anomaly. This cyclonic anomaly attracts moisture to itself and away from the South African summer rainfall region. Some other patterns exhibit widespread positive geopotential height anomalies over the region, with associated divergent moisture flux. In these cases, flow into the region is either from the west/southwest or from the south, bringing in cooler, less-moist air from the mid-latitude oceans further south.

Dry spells over the summer rainfall region often have weak divergent moisture fluxes. Most cases have a positive mid-level geopotential height anomaly over the region, suppressing convection even when lowlevel moisture is available. Zonal mid-latitude westerlies are enhanced over southern South Africa in some dry cases. Moisture transport during dry spells seems more consistent than during wet spells, and the patterns are easier to understand since low-level divergence and subsidence are present and the relatively small amount of moisture flowing into the region limits any rain that falls.

\subsection{Summary of synoptic wet spell characteristics}

The 8 synoptic wet spells showed 2 predominant patterns of rainfall, namely, a northwest-southeastoriented band, typically associated with a tropical-temperate trough, as in the spells of October 1991 and February 1988 (Fig. 4), and secondly, widespread precipitation over eastern South Africa as in November 1995 (Fig. 5). The latter is generally associated with a ridging high over the east coast and an easterly low or wave over the northern interior.

Moisture flux patterns for wet spells may vary, but usually exhibit enhanced easterly inflow from the SWIO/Mozambique Channel or northeasterly flow originating further north over the tropical western Indian Ocean. Moisture converges over the summer rainfall region in both mean and anomaly flux plots. Wet spells are often anticyclonic in the sense that a ridge exists over the east coast, associated with a positive geopotential height anomaly occurring south or southeast of South Africa. This positive anomaly enhances the inflow of low-level moisture from the SWIO, but it is far enough to the southeast (unlike the dry cases) that anticyclonic subsidence does not occur over the summer rainfall region. Other wet spells show a strong cyclonic anomaly north of the region, which may draw in moisture from the tropical South Atlantic as well as from the South Indian Ocean, if it is located near the Angola/Namibia low. Relative convergence occurs in the western and/or northern parts of the region and neighbouring areas (favourable for cloudbands), with relative divergence over the east coast or south of the region. Some wet spells show strong relative convergence surrounded by regions of divergence. This is apparent for the wet spell of 23-27 January 1996, where there is a strong cyclonic anomaly centred over northern South Africa (see Fig. 6) and extending out into the adjacent oceans, consistent with the mature phase of a La Niña event (Reason et al. 2000). In general, negative OLR anomalies are present in all the synoptic wet spells, as would be expected, indicating enhanced convection and tending to coincide with regions of low-level convergence.

\section{WET AND DRY EARLY AND LATE SUMMERS}

This section examines the OND and JFM climatologies of precipitation and moisture transport, and the atmospheric conditions during anomalously wet and dry OND and JFM seasons. Climatology and composite plots are included for this purpose. Monthly climatologies of rainfall and circulation variables (not shown) indicate that a change occurs between early and late summer, consistent with many previous stud- 
a

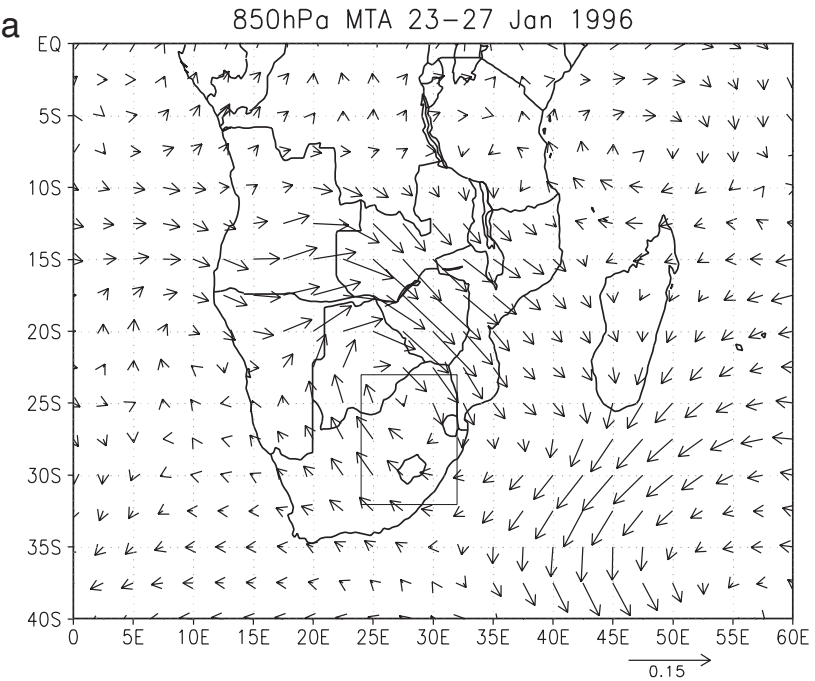

b

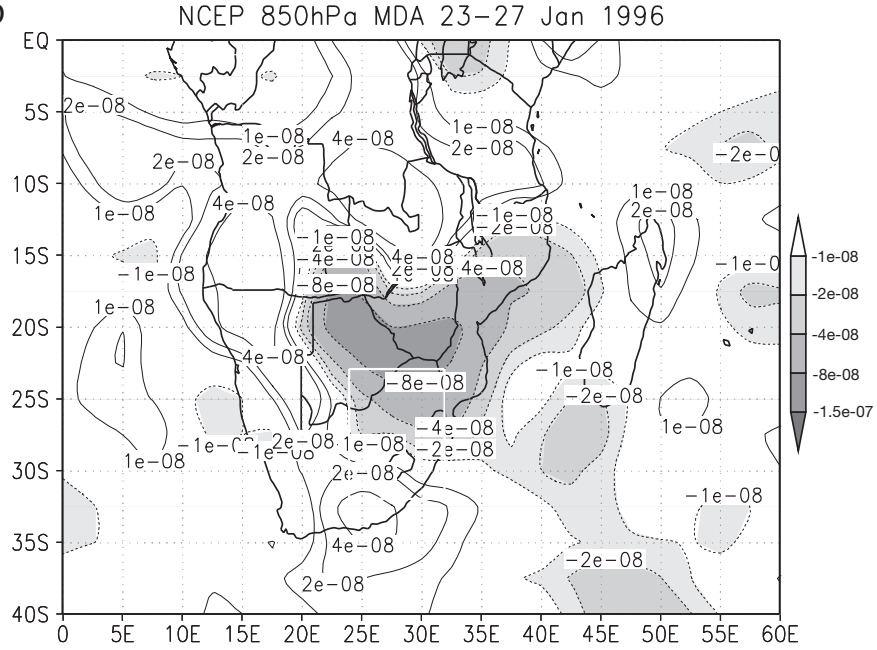

Fig. 6. Wet spell 23-27 January $1996850 \mathrm{hPa}$ anomalies: (a) $850 \mathrm{hPa}$ moisture transport (MTA) (scale vector size $0.15 \mathrm{~kg} \mathrm{~kg}^{-1} \mathrm{~ms}^{-1}$ ), (b) $850 \mathrm{hPa}$ moisture divergence (MDA) (negative anomalies shaded, contours are plotted at levels of $\pm 1 \times 10^{-8}, 2 \times 10^{-8}, 4 \times 10^{-8}, 8 \times 10^{-8} \mathrm{~kg} \mathrm{~kg}^{-1} \mathrm{~s}^{-1}$ )

ies (e.g. Tyson 1986, D'Abreton \& Tyson 1995, 1996, Mason \& Jury 1997). In JFM, the ITCZ typically lies further south, i.e. over Mozambique and northern Zimbabwe, and more obvious convergence of moisture occurs over low-latitude southern Africa, originating from the SWIO, the equatorial western Indian Ocean and the tropical southeast Atlantic.

The OND and JFM climatologies of rainfall (Fig. 7), moisture transport (Fig. 8) and moisture divergence (Fig. 9) show the subtle evolution of the patterns as the summer progresses and the tropical features become more dominant. Late-summer rainfall patterns are similar to those of OND, but with higher values. The $850 \mathrm{hPa}$ moisture transport climatologies (Fig. 8) are similar over most of South Africa, but they become more southeasterly in JFM over northern South Africa, southern Mozambique and Zimbabwe as the South Indian anticyclone moves southeastwards. Also, in late summer, anticyclonic flow strengthens over eastern South Africa and cyclonic features over Angola and the Mozambique Channel are more pronounced, enhancing the flux of moisture from the SWIO and tropical SE Atlantic. As the ITCZ moves further south over Madagascar and Mozambique in JFM, the easterly flow south of it strengthens and adjusts more prominently to the significant topography of southern Madagascar, Zimbabwe and eastern South Africa, leading to a pronounced trough in the southern Mozambique

a

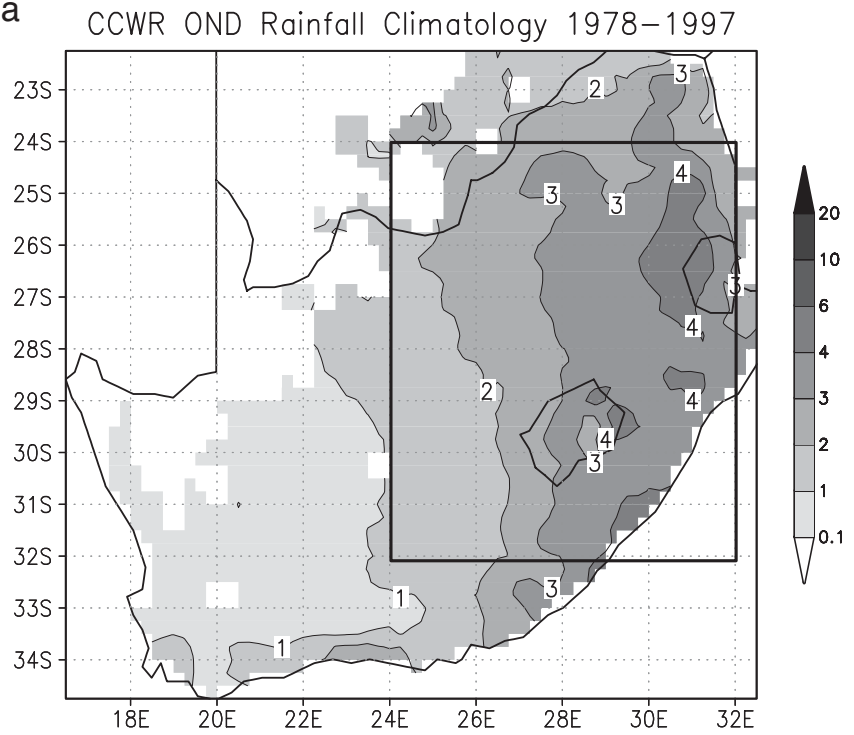

b

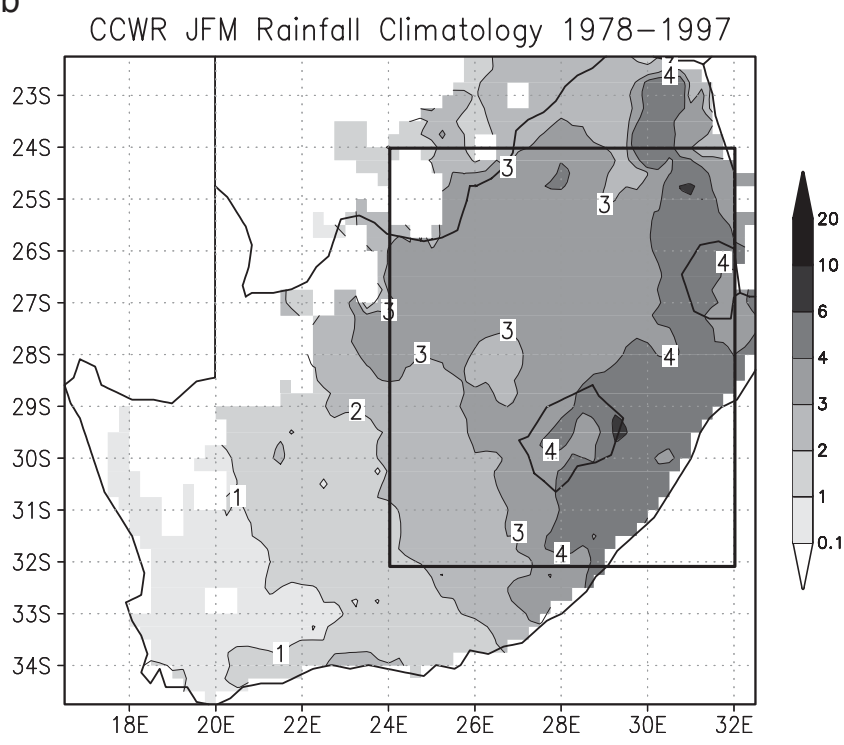

Fig. 7. CCWR rainfall climatology, 1978-1997: (a) OND, (b) JFM (contour levels 0.1, 1, 2, 3, 4, 6, 10, $20 \mathrm{~mm} \mathrm{~d}^{-1}$ ) 
a

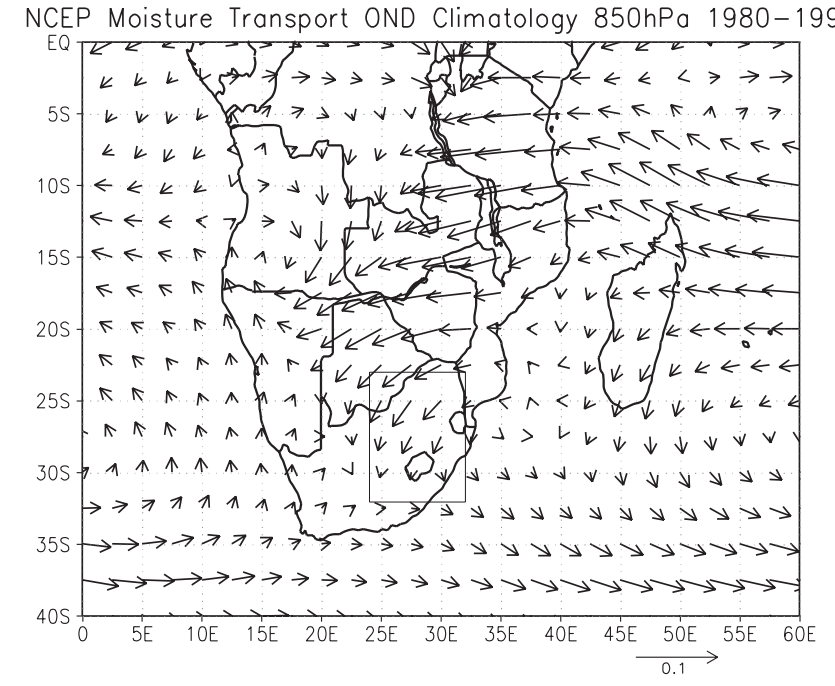

NCEP Moisture Transport JFM Climatology 850hPa 1980-1999

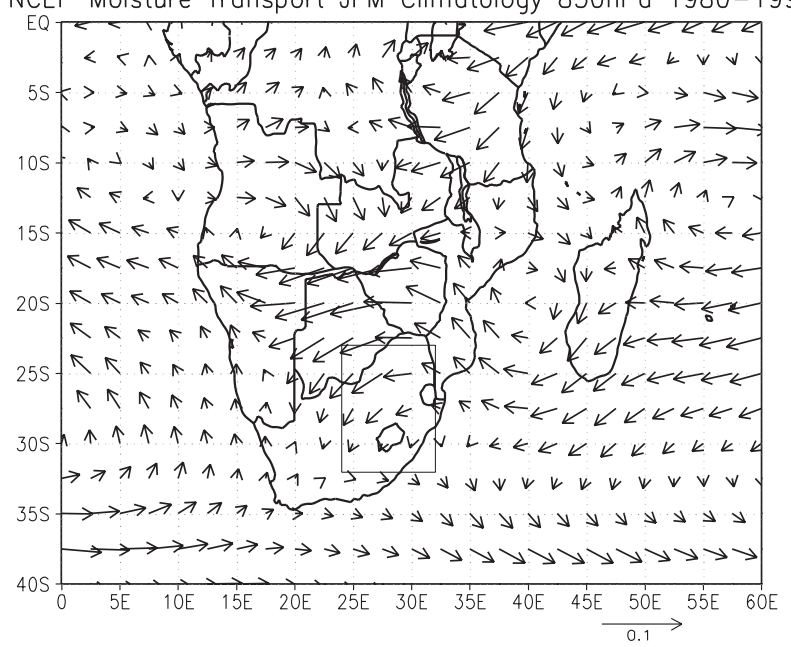

Fig. 8. NCEP $850 \mathrm{hPa}$ moisture transport climatology, 1980-1999 (scale vector size $0.1 \mathrm{~kg} \mathrm{~kg}^{-1} \mathrm{~ms}^{-1}$ ): (a) OND, (b) JFM

Channel. The Angola/Namibia low is also significantly stronger in JFM, intensifying its contribution as a tropical source region for tropical-temperate troughs, which bring much of the summer rainfall. A similar $850 \mathrm{hPa}$ moisture divergence pattern exists in OND and JFM (Fig. 9), with regions of moisture divergence over Zimbabwe, Mozambique and up the eastern African coast, and a northwest-southeast-oriented band of convergence across central South Africa up to southern Angola. A noticeable difference between the 2 seasons (Fig. 10) is the weaker divergence along the eastern coast in late summer and increased cyclonic circulation over the Mozambique Channel and Angola/northern Namibia. This reduced divergence relates to the moisture transport climatologies, where later in the summer a strong southeasterly moisture flow enters the region from the southern Mozambique Channel.

Moisture transport anomalies for the dry OND composite (Fig. 11a) show anomalous southwesterly moisture influx from the southeast Atlantic, whereas the wet OND composite (Fig. 11b) shows anomalous northeasterly moisture flux over northern South Africa and Zimbabwe. These fluxes reduce and enhance the mean moisture flow into the summer rainfall region respectively. The cyclonic feature over Angola/ Namibia is enhanced (reduced) in wet ONDs (dry ONDs), and the corresponding increase (reduction) in the amount of moisture imported from the tropical South Atlantic leads to enhanced (reduced) moisture convergence in the source region of tropical-temperate troughs. In dry JFMs (Fig. 11c) a weak westerly or southwesterly moisture flux anomaly occurs over
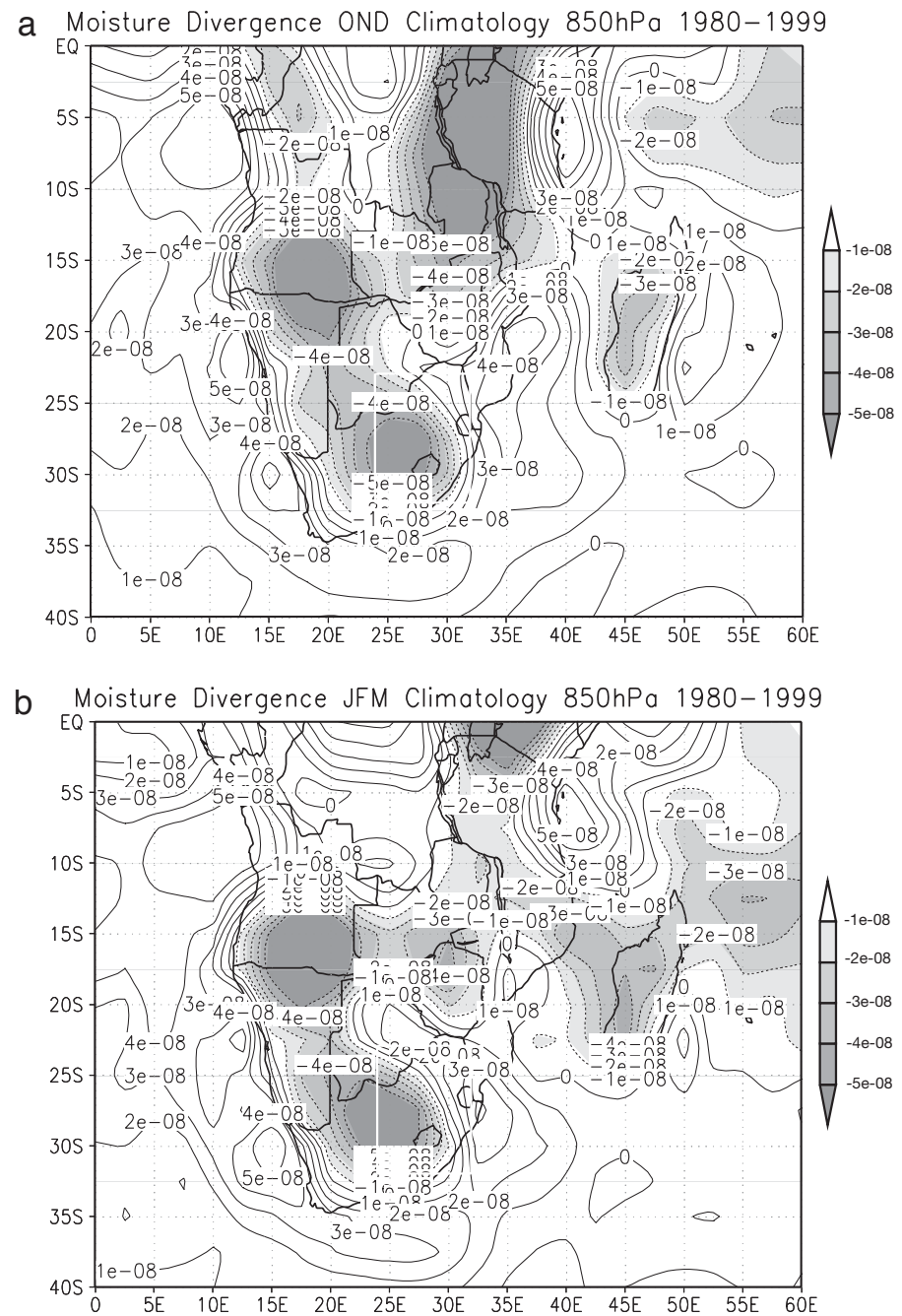

Fig. 9. NCEP $850 \mathrm{hPa}$ moisture divergence climatology, 1980-1999 (negative values shaded, contour interval $1 \times 10^{-8}$ $\mathrm{kg} \mathrm{kg}^{-1} \mathrm{~s}^{-1}$ ): (a) OND, (b) JFM 
a

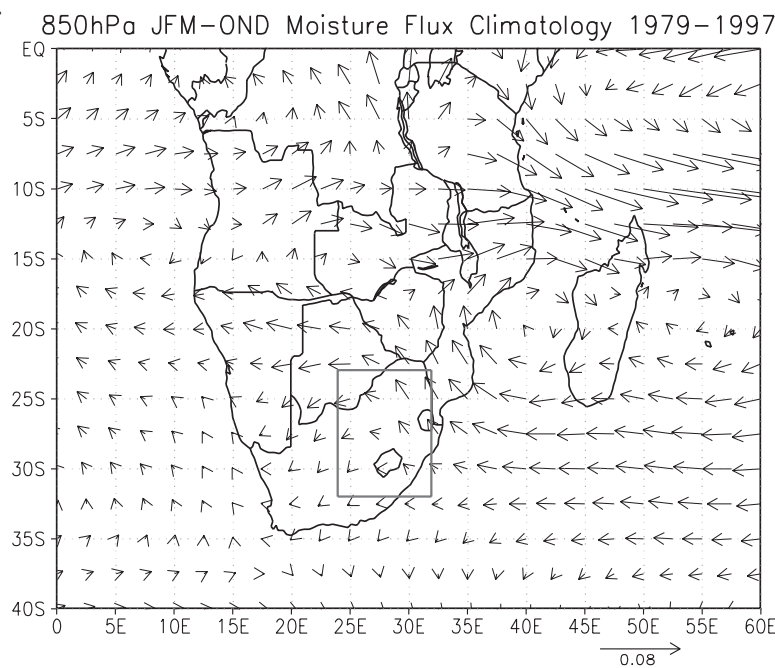

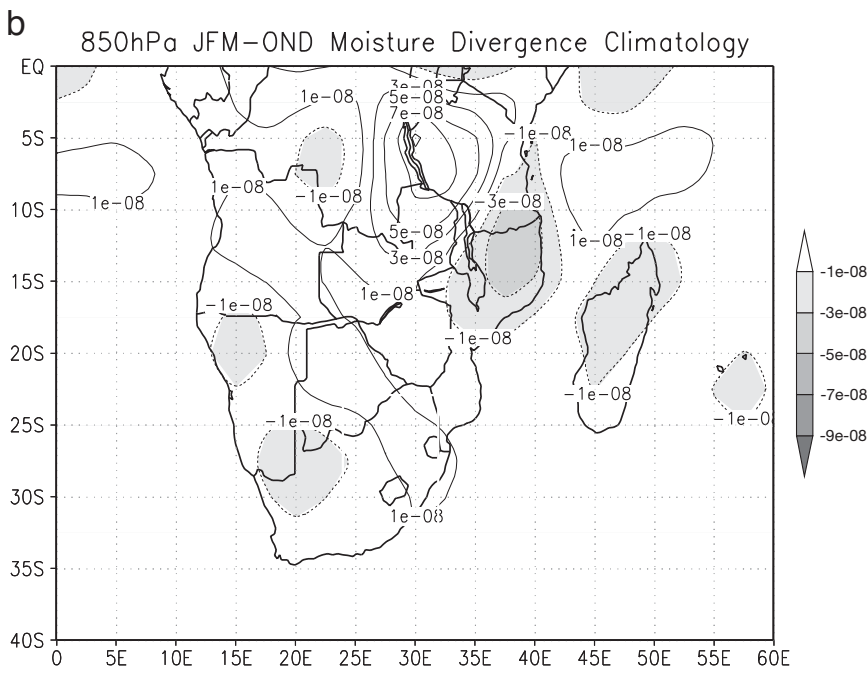

Fig. 10. NCEP 850 hPa moisture flux and divergence climatology difference: JFM minus OND. (a) Moisture flux (scale vector size $0.08 \mathrm{~kg} \mathrm{~kg}^{-1} \mathrm{~ms}^{-1}$ ), (b) moisture divergence (contour interval $2 \times 10^{-8} \mathrm{~kg} \mathrm{~kg}^{-1} \mathrm{~s}^{-1}$ )

a

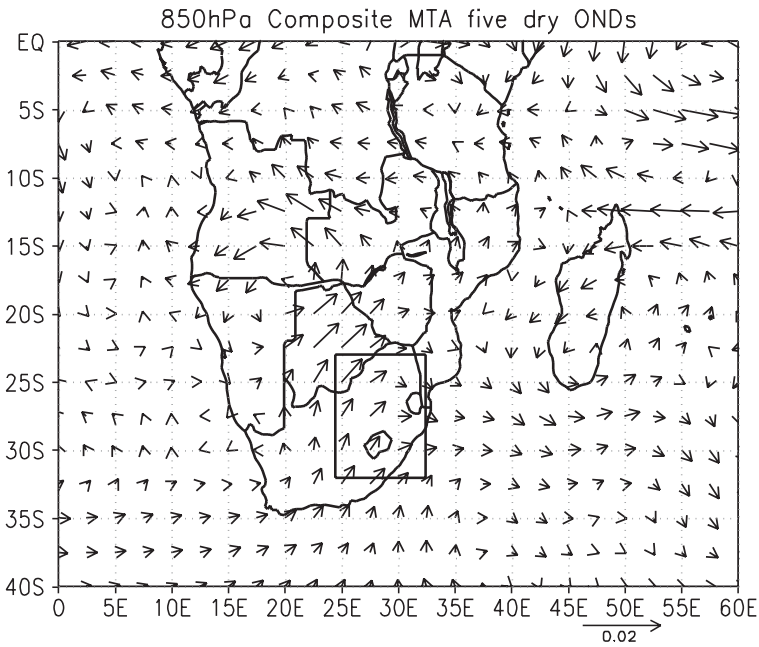

C

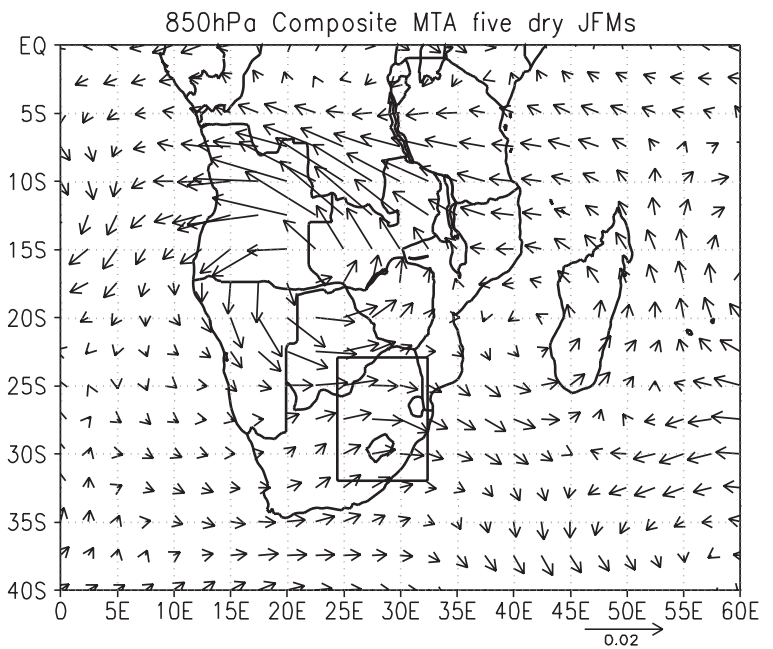

b

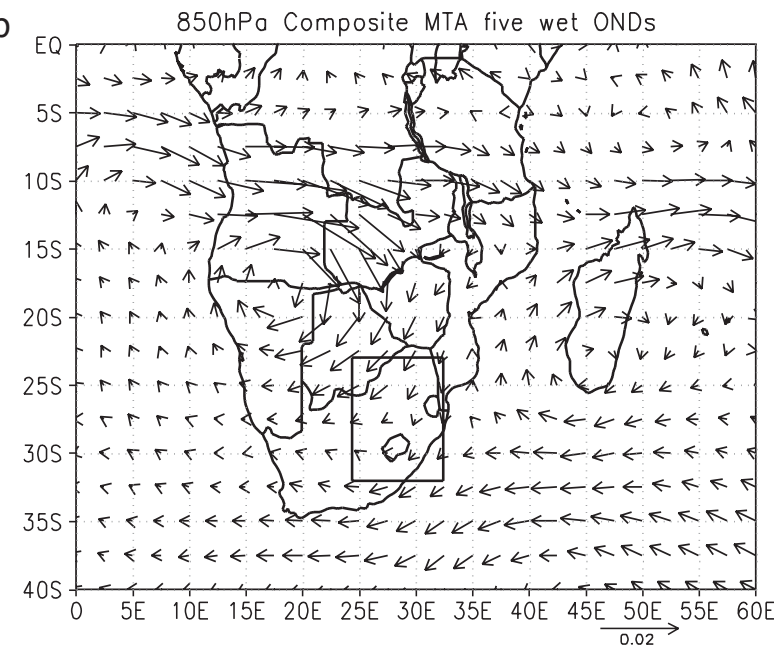

d

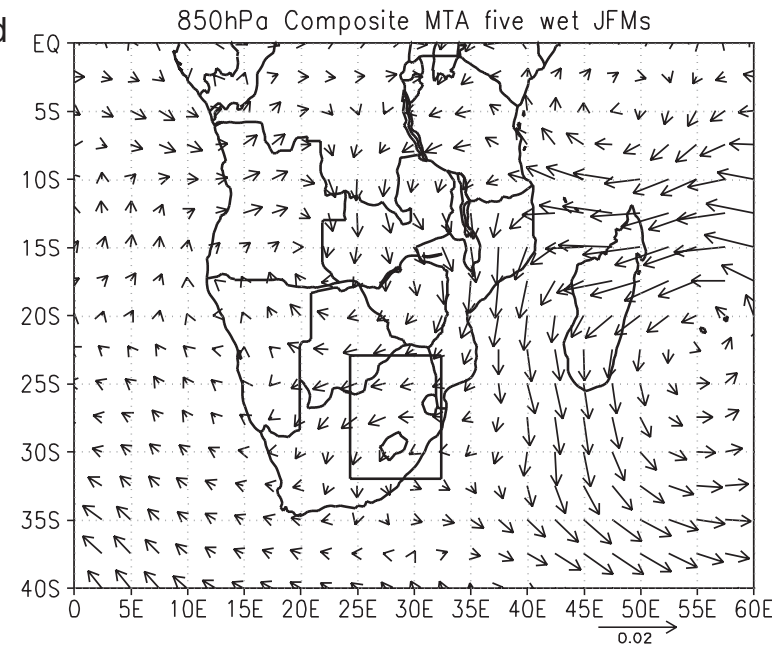

Fig. 11. NCEP 850 hPa composite moisture transport anomaly (MTA) (vector size $0.02 \mathrm{~kg} \mathrm{~kg}^{-1} \mathrm{~ms}^{-1}$ ): (a) 5 dry ONDs (1994, 1990 , 1982, 1984 and 1981), (b) 5 wet ONDs (1995, 1993, 1996, 1989 and 1983), (c) 5 dry JFMs (1982, 1983, 1992, 1986 and 1979), (d) 5 wet JFMs (1996, 1991, 1988, 1981 and 1997) 
South Africa, effectively reducing the mean easterly moisture flow into the region. Furthermore, the significantly weakened Angola/Namibia low reduces cloudband activity across South Africa. Wet JFMs (Fig. 11d) show enhanced northerly inflow of moisture from the western tropical Indian Ocean over northeast South Africa, which is favourable for good rains. The cyclonic feature over Angola/Namibia (Fig. 8b) is enhanced in the wet JFMs (by about 10\%), but the magnitude of the anomaly here is not as large as its corresponding weakening in the dry JFMs (about a $20 \%$ decrease).

Similarly, low-level divergence anomalies over South Africa for ONDs (Fig. 12a,b) tend to show a weakening (strengthening) of the climatological patterns of divergence in dry (wet) ONDs. Anomalous divergence (convergence) over the western (eastern) half of South Africa in northwest-southeast bands occur in dry ONDs, suggesting an eastward shift in the pre- ferred location of the tropical-temperate troughs towards the SWIO. The reverse occurs in wet ONDs, where strong relative convergence coincides with the Angola/Namibia low, producing a relative strengthening of the mean divergence-convergence pattern. This enhanced convergence suggests an increase in the occurrence of tropical-temperate troughs in wet years across the summer rainfall region. JFM moisture divergence anomaly composites (Fig. 12c,d) show weak anomalies over South Africa (about $5 \%$ of climatology) and stronger anomalies in the Angola/Namibia region (about $10-20 \%$ ), where either the truncated easterly troughs or the tropical-temperate troughs originate. Dry JFMs show weak relative convergence over southeastern South Africa and strong relative divergence weakening the Angola/Namibia low. Wet JFMs show weak relative low-level divergence over eastern South Africa and most of the subcontinent, and strong relative a

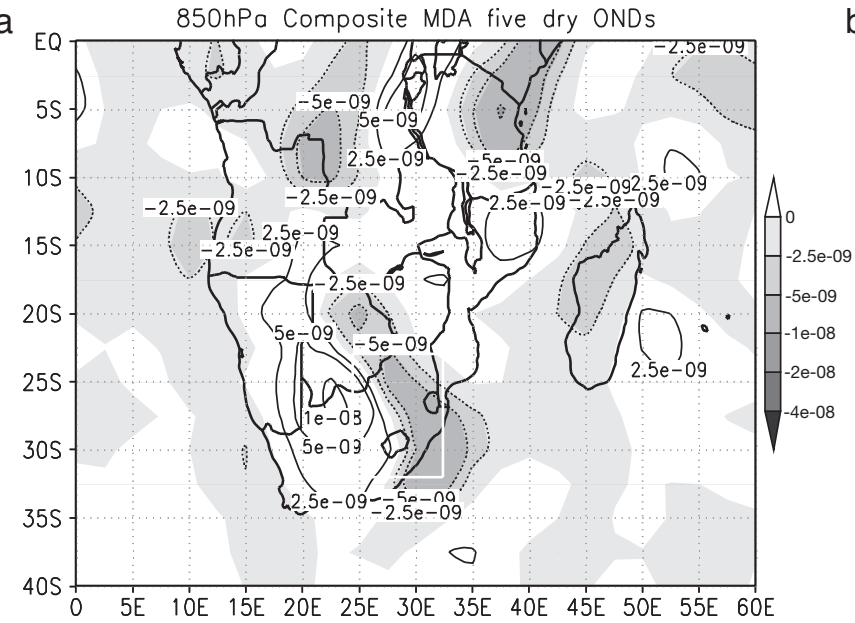

C

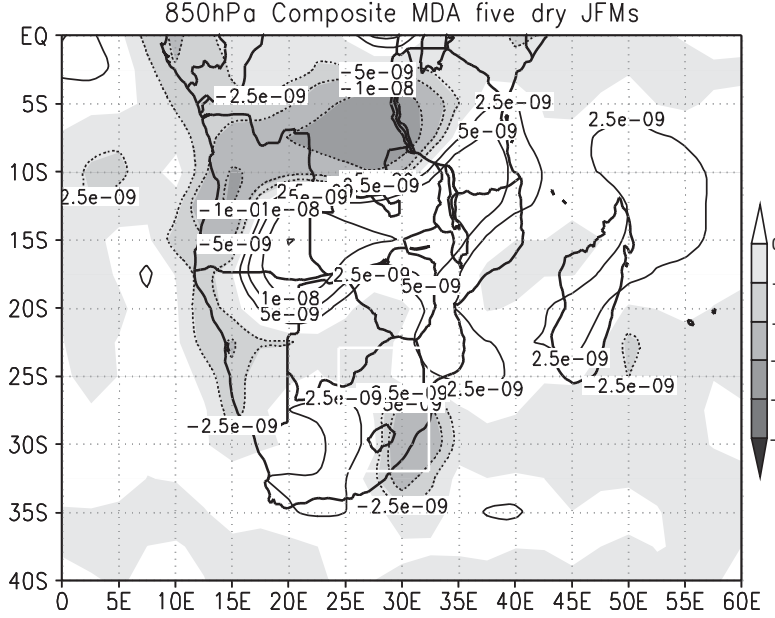

b

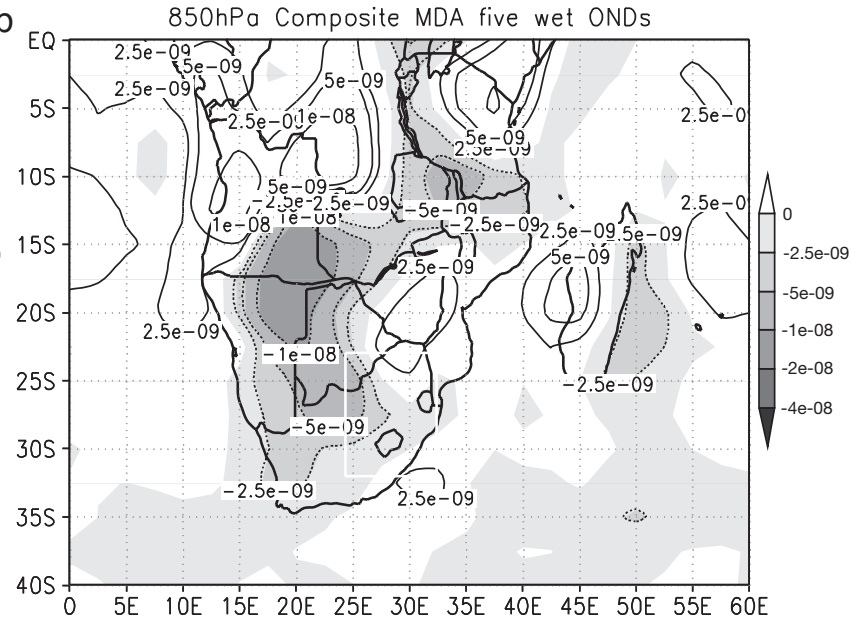

d

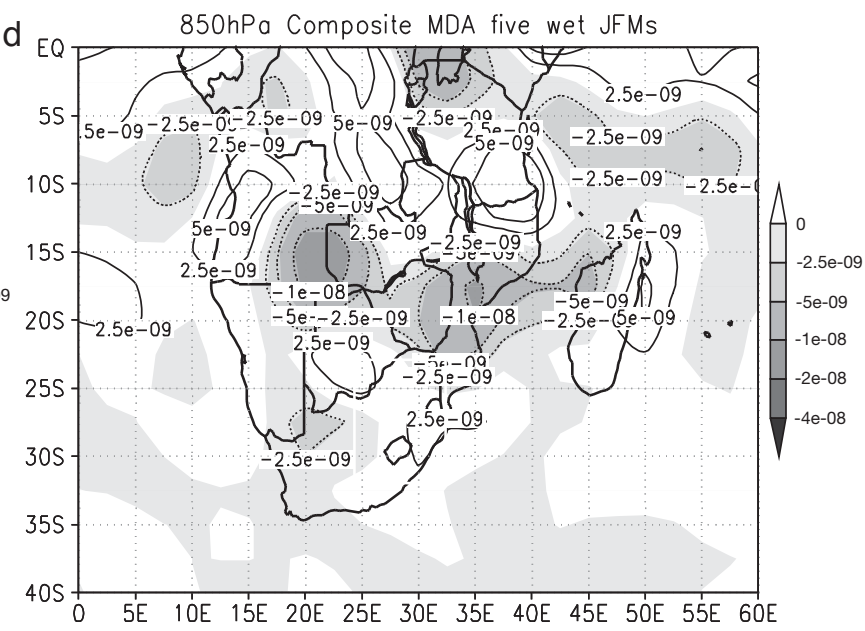

Fig. 12. NCEP 850 hPa composite moisture divergence anomaly (MDA) (negative anomalies shaded, contour levels $\pm 0.25 \times 10^{-8}$, $\left.0.5 \times 10^{-8}, 1 \times 10^{-8}, 2 \times 10^{-8}, 4 \times 10^{-8} \mathrm{~kg} \mathrm{~kg}^{-1} \mathrm{~s}^{-1}\right)$ : (a) 5 dry ONDs $(1994,1990,1982,1984$ and 1981), (b) 5 wet ONDs (1995, 1993, 1996, 1989 and 1983), (c) 5 dry JFMs (1982, 1983, 1992, 1986 and 1979), (d) 5 wet JFMs (1996, 1991, 1988, 1981 and 1997) 
convergence over Angola/Namibia, thereby enhancing the tropical low, from which rain-producing troughs emanate. In wet JFMs, relative convergence over Zimbabwe, Zambia and Mozambique shows that the ITCZ over tropical southeastern Africa is enhanced and shifted southwards, whereas during dry JFMs relative divergence weakens the ITCZ here. The difference between wet and dry seasons is clearer in the composite of wet years minus dry years (Fig. 13), where again the Angola/Namibia low dominates the plot.

Geopotential height and OLR anomaly composites (not shown) were consistent with the moisture transport and divergence plots. They showed an intense low over Angola/Namibia and a trough over western South Africa in wet ONDs, thereby favouring the formation of tropical-temperate troughs across South Africa. Dry ONDs show a high in the tropics and over the western half of South Africa and a low in the eastern half, extending southeastwards. As expected, positive OLR anomalies over South Africa, indicating decreased convection, occurred in dry years, and decreased OLR (enhanced convection) occurs over the subcontinent in wet ONDs, centred over Botswana. Similarly, JFM geopotential height and OLR anomalies (not shown) also agree with the moisture transport anomalies. Dry late summers show a widespread high across southern Africa, a low over the South Atlantic south and southwest of South Africa and a trough over the east coast of South Africa; so tropical-temperate troughs are more likely to occur over Mozambique and east of South Africa. Positive OLR anomalies, indicating decreased convection, occur over South Africa. Wet JFMs show a strong tropical low over Angola/Namibia with a trough extending in a northwest-southeast direction across South Africa and a high geopotential height east of Madagascar and decreased OLR (enhanced convection) centred over Zimbabwe. a

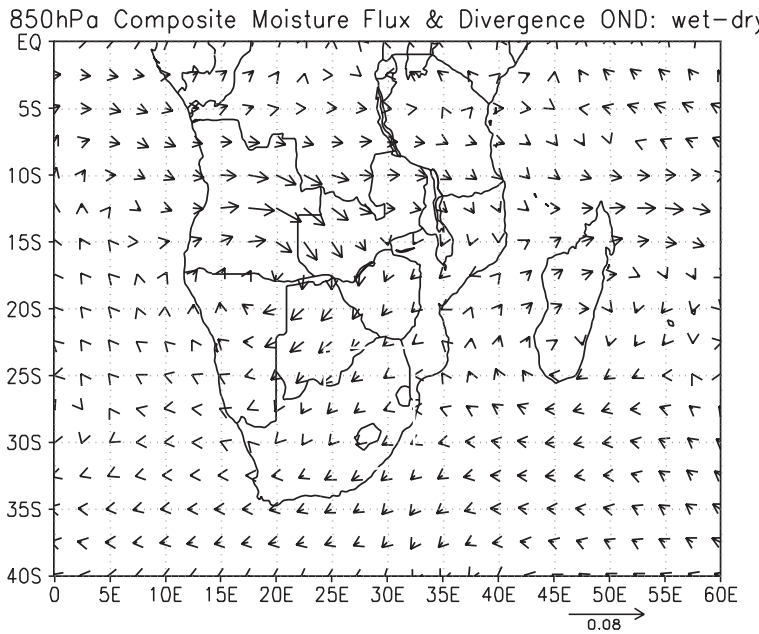

C

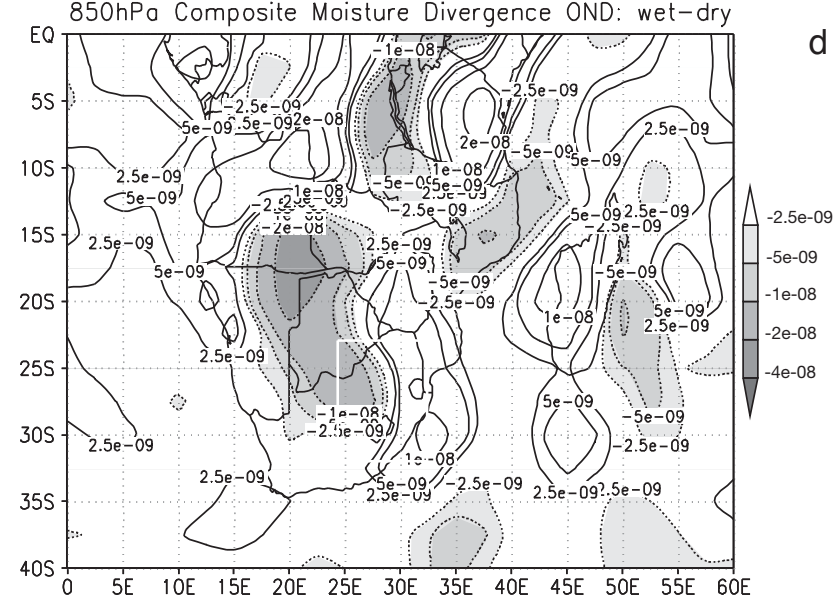

b

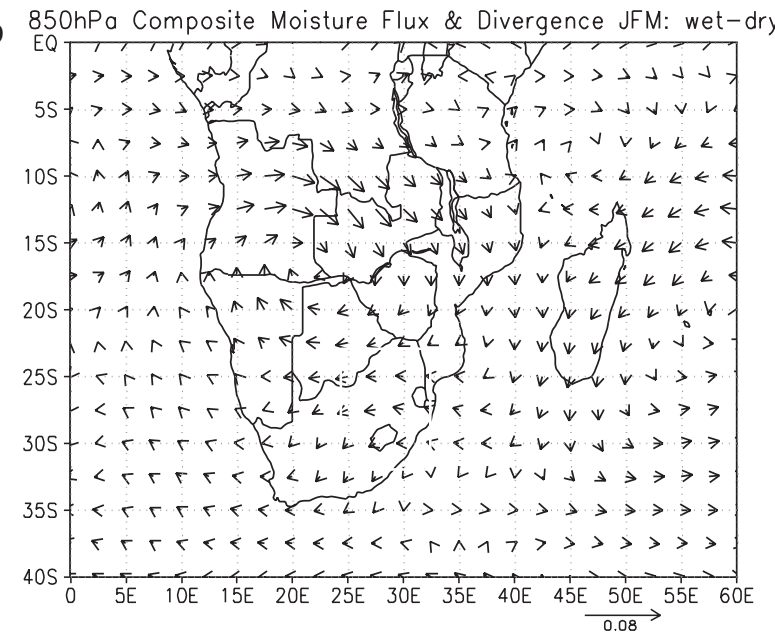

d

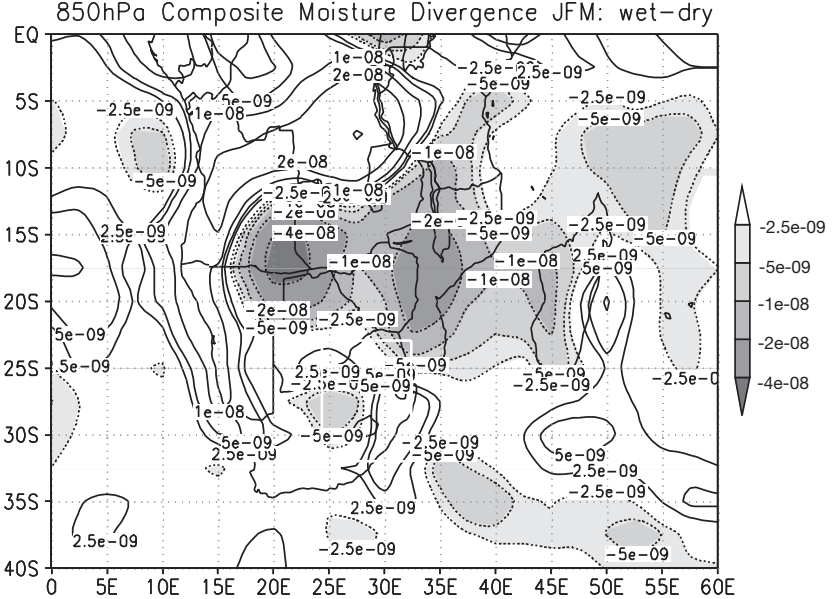

Fig. 13. NCEP $850 \mathrm{hPa}$ composites of wet years minus dry years: $(\mathrm{a}, \mathrm{b})$ moisture flux (scale vector size $\left.0.08 \mathrm{~kg} \mathrm{~kg}^{-1} \mathrm{~ms}^{-1}\right)(\mathrm{c}, \mathrm{d}) \mathrm{mois}^{-}$ ture divergence (negative anomalies shaded, contour levels $\left.\pm 0.25 \times 10^{-8}, 0.5 \times 10^{-8}, 1 \times 10^{-8}, 2 \times 10^{-8}, 4 \times 10^{-8} \mathrm{~kg} \mathrm{~kg}^{-1} \mathrm{~s}^{-1}\right):(\mathrm{a}, \mathrm{c})$ ONDs (1995, 1993, 1996, 1989, 1983 minus 1994, 1990, 1982, 1984, 1981); (b,d) JFMs (1996, 1991, 1988, 1981, 1997 minus 1982, $1983,1992,1986,1979)$ 
In general, dry ONDs and JFMs are both characterised by reduced moisture transport and moisture divergence patterns, compared to the climatology, and wet ONDs and JFMs are characterised by an enhancement of the climatological pattern. The change in the cyclonic feature over Angola/Namibia is the most noticeable feature in wet ONDs and dry JFMs, with the associated moisture flux anomaly over eastern South Africa from the northeast and southwest, respectively. This feature is weaker in dry ONDs, but the moisture flux anomaly is clearly southwesterly, and the divergence-convergence pattern is similar to, but weaker than, the climatology. Wet JFMs show an increase in northerly moisture flux over the Mozambique Channel and easterly flux anomaly over the region, with a smaller, but still noticeable, enhancement of the Angola/Namibia low.

The moisture flux and divergence in wet and dry seasons show differences in moisture flowing into the summer rainfall region and the strength of convergence and divergence over South Africa and surrounding regions. However, the composite anomaly values (Fig. 12) are relatively small compared to the climatology, being between 2 and $20 \%$ of the values at the centre of convergence and divergence regions around South Africa in the climatology (Fig. 9). This finding reinforces the need to consider not only seasonal anomalies but also the synoptic wet and dry spells that occur within anomalously wet and dry seasons. Reduced, enhanced or shifted convergence during these seasons influences the formation, occurrence and preferred locations of tropical-temperate troughs and other rainfall-producing systems. Changes in the low over Angola/Namibia affect moisture flux across South Africa via the associated wind patterns and their influence on tropical temperate trough and cloudband activity.

\section{ANALYSIS OF WET AND DRY SPELL CHARAC- TERISTICS DURING OND AND JFM SEASONS}

An exploration of the daily rainfall timeseries, focussing on the characteristics of wet and dry spells within OND and JFM seasons, was performed in order to determine the nature of this higher frequency variability during anomalously wet and dry seasons. Several attributes of the wet spell and dry spells during OND and JFM seasons were derived from the daily area-averaged rainfall data from 1970-1997. These included seasonal mean of daily rainfall, the number and mean duration of wet and dry spells during the season, and the mean wet spell intensity.

Wet and dry spells were defined as at least 3 consecutive days having area-average rainfall above or below $1 \mathrm{~mm} \mathrm{~d}^{-1}$, respectively. More intense wet spells were counted as those with at least 3 consecutive days of over $5 \mathrm{~mm} \mathrm{~d}^{-1}$. Table 3 gives the mean and standard deviation for each variable, for OND and JFM seasons, while Table 4 shows values for the dry summers 1982/83 and 1991/92 and wet summers 1987/88 and

Table 3. OND and JFM wet and dry spell variables

\begin{tabular}{|llcccc|}
\hline \multicolumn{1}{c}{ Description of variable } & OND mean & $\begin{array}{c}\text { OND standard } \\
\text { deviation }\end{array}$ & $\begin{array}{c}\text { JFM mean } \\
\text { JFM standard } \\
\text { deviation }\end{array}$ \\
\hline 1 & Seasonal mean rainfall & 2.77 & 0.477 & 3.47 & 1.01 \\
2 & Numbers of wet spells of at least 3 d over 1 mm & 7.25 & 1.506 & 5.64 & 1.77 \\
3 & Numbers of wet spells of at least 3 d over 5 mm & 1.86 & 0.756 & 2.64 & 1.810 \\
4 & Mean wet spell (>1 mm) duration (d) & 8.21 & 2.022 & 11.3 & 4.627 \\
5 & Mean wet spell intensity (mm d ${ }^{-1}$ ) & 3.56 & 0.511 & 2.68 & 1.219 \\
6 & Number of dry spells of at least 3 d under 1 mm & 4.54 & 1.319 & 4.51 & 1.728 \\
7 & Mean dry spell duration (d) & 4.68 & 1.093 & & \\
\hline
\end{tabular}

Table 4 . Wet and dry spell variables over the whole summer (October-March): mean and values in wet and dry summers

\begin{tabular}{|c|c|c|c|c|c|c|}
\hline & Description of variable & $\begin{array}{l}\text { Oct-Mar } \\
\text { mean }\end{array}$ & $\begin{array}{c}\text { Dry } \\
1982 / 83\end{array}$ & $\begin{array}{c}\text { Dry } \\
1991 / 92\end{array}$ & $\begin{array}{c}\text { Wet } \\
1987 / 88\end{array}$ & $\begin{array}{c}\text { Wet } \\
1995 / 96\end{array}$ \\
\hline 1 & Seasonal mean rainfall & 2.69 & 2.09 & 2.27 & 3.66 & 4.35 \\
\hline 2 & Numbers of wet spells of at least 3 days over $1 \mathrm{~mm}$ & 13.6 & 16 & 18 & 11 & 11 \\
\hline 3 & Numbers of wet spells of at least 3 days over $5 \mathrm{~mm}$ & 4.64 & 2 & 1 & 7 & 7 \\
\hline 4 & Mean wet spell $>1 \mathrm{~mm}$ duration $(\mathrm{d})$ & 8.2 & 6.06 & 6.89 & 11.9 & 8.91 \\
\hline 5 & Mean wet spell intensity $\left(\mathrm{mm} \mathrm{d}^{-1}\right)$ & 3.66 & 2.96 & 2.79 & 3.56 & 4.04 \\
\hline 6 & Number of dry spells of at least 3 days under $1 \mathrm{~mm}$ & 4.8 & 10 & 6 & 8 & 8 \\
\hline 7 & Mean dry spell duration (d) & & 4.9 & 5.3 & 4.25 & 3.0 \\
\hline
\end{tabular}


1995/96 compared with means for the whole summer. Both the wet summers have a higher than average number of intense wet spells (i.e. more than $5 \mathrm{~mm} \mathrm{~d}^{-1}$ ) and shorter dry spells, but the wet spells are significantly longer than average in 1987/88 and considerably wetter than average in 1995/96. The dry summers both exhibit a large reduction in the number of intense wet spells of more than $5 \mathrm{~mm} \mathrm{~d}^{-1}$, and generally shorter wet spells when these occur. However, 1982/83 has a larger number of dry spells, whereas 1991/92 has dry spells that last longer than average. Both dry seasons have a larger number of less intense wet spells than average, suggesting that the changes in moisture flux and low-level divergence discussed in Section 4 influence the intensity of the synoptic rain-producing system such as the tropical-temperate troughs over South Africa.

To investigate this further, correlations averaged over 28 yr were calculated between the variables. This revealed positive correlations of seasonal mean rainfall with wet-spell duration $(+0.75$ for OND and +0.74 for JFM) and wet-spell intensity ( +0.58 for OND and +0.52 for JFM), but number of wet spells was negatively correlated $(-0.28$ for OND and -0.75 for JFM). This shows that, in general, wetter seasons are characterised by longer or more intense wet spells rather than an increased number of wet spells (of at least $3 \mathrm{~d}$ over $1 \mathrm{~mm} \mathrm{~d}^{-1}$ ). Similarly, number of dry spells correlated negatively with the seasonal mean (about -0.44 for both OND and JFM), indicating that wetter seasons also tend to have fewer dry spells, i.e. fewer transitions between wet and dry conditions, with longer and more intense wet spells.

For example, the OND season with the most wet spells, as defined here, was the drier than average OND season of 1991, with 10 wet spells over $1 \mathrm{~mm} \mathrm{~d}^{-1}$, but only one of these was consistently over $5 \mathrm{~mm} \mathrm{~d}^{-1}$, and the average duration and the average intensity of the wet spells were both below average. Conversely, the wet OND season of 1995 had fewer than average wet spells (6), but half of them were over $5 \mathrm{~mm} \mathrm{~d}^{-1}$, and on average they were longer and much more intense, so these factors made it a wet OND season overall.

\section{DISCUSSION AND CONCLUSIONS}

This investigation of wet and dry conditions over the South African summer rainfall region showed important similarities and some degree of variation in the observed circulation patterns for the various wet and dry cases. These similarities and differences were revealed by inspecting anomalies of moisture transport and moisture divergence for wet and dry seasons and synoptic spells.
The research presented here builds on previous work, briefly described in the introduction, and highlights details of moisture transport and other variables during specific wet and dry spells and composites of wet and dry seasons. These results generally agree with schematic representations (Tyson \& PrestonWhyte 2000) of wet and dry conditions on seasonal and longer timescales. However, these schematics tend to miss out the complexity of variability on synoptic-tointerannual timescales and are only suggestive. An important omission, which this study has emphasised, is the significance of the Angola/Namibia low for South African rainfall variability.

Moisture transport, moisture divergence, OLR and geopotential height were examined in order to understand the circulation patterns and identify locations of moisture source regions. Both wet and dry spells show several different associated patterns e.g. 3 dry spells have a cyclonic anomaly off the east coast. Most of the wet spells show increased influx of moisture from the SWIO and convergence in the summer rainfall region. Seasonal composites for wet or dry early and late summers show that commonalities are present, such as predominant circulation types and direction of moisture flux. In dry early summers (OND), the prevailing flow into the region is from the south or the southwest converging further north, while in wet OND seasons there is a northeasterly flow of moist tropical air into the region. So the wetter seasons and spells both tend to be dominated by anomalous easterly or northeasterly moisture flux, converging over South Africa; the drier seasons tend to be dominated by an anticyclonic anomaly over the land and anomalous southerly moisture flux over the eastern half of the country that emanates from the mid-latitudes. The intensity of the Angola/Namibia low clearly relates to the moisture flux pattern over northern South Africa, as was discussed in Section 4.

In summary, the dry synoptic spells are typically characterised by a decreased contribution of moisture from the tropical/subtropical SWIO into South Africa and widespread relative divergence over or near the region. The predominant inflow of moisture is from the south or southwest, bringing in cooler, less moist air, mostly from the South Atlantic. Geopotential-height anomalies are generally positive (negative) over the western (eastern) part of the region.

Wet-spell synoptic conditions were dominated either by a tropical-temperate trough (e.g. 20-24 February 1988; Fig. 4) or by a ridging anticyclone along the coast, with an easterly low over the northern interior (e.g. 17-21 November 1995; Fig. 5). Several wet-spell geopotential-height anomalies show an opposite pattern to dry spells, i.e. low over the west and high over the east of South Africa, often due to a large anticy- 
clonic anomaly to the south, with a ridge over the east coast. This brings in warm, moist Indian Ocean air from the east or northeast.

The difference in conditions exhibited by the wet and dry spells considered raises the question of how much the rainfall characteristics are determined by the large-scale moisture transport circulation and how much by the local forcing. This is an important question that should be investigated in further studies.

The effects of individual wet and dry spells on the whole season determine the interannual variability of rainfall in the region, as the discussion of wet and dry spell statistics has shown. Wet seasons are more likely to have fewer, but longer or more intense wet spells rather than an increased number of wet spells. This relation of wet and dry spells to wetter- and drier-thannormal seasons should be investigated further in more detail. Further work is needed to analyse moisturetransport patterns during wet and dry spells in order to explain these seasonal rainfall characteristics. The work presented here has highlighted the significance of the Angola/Namibia low and the need to consider higher frequency variability when trying to understand interannual variations in seasonal rainfall over semi-arid South Africa.

Seasonal forecasting of South African rainfall using dynamical models is just beginning in this country, and current results suggest that models need to be capable of representing the frequency, location and intensity of synoptic rainfall-producing systems with some accuracy in order for this to be successful. Furthermore, the importance of the Angola/Namibia low suggests that regional models need to have an accurate representation of local land-surface-atmosphere interactions and moisture inflow from the neighbouring tropical southeast Atlantic, highlighting the need for adequate regional soil, vegetation and SST data.

Acknowledgements. This work was supported out of funding from the Water Research Commission for project K5/1012 to B.C.H. The NOAA-CIRES Climate Diagnostics Center, Boulder, Colorado, USA, is acknowledged for use of the CDC Website (http://www.cdc.noaa.gov/) to generate OLR and SST anomaly plots from the NCEP Reanalysis data.

\section{LITERATURE CITED}

Allan RJ, Lindesay JA, Parker DE (1996) The El-NiñoSouthern Oscillation and climate variability. CSIRO Publishing, Collingwood, VIC

Crimp SJ, Lutjeharms JRE, Mason SJ (1998) Sensitivity of a tropical-temperate trough to sea-surface temperature anomalies in the Agulhas retroflection region. Water SA $24: 93-100$

Editorial responsibility: Andrew Comrie,

Tucson, Arizona, USA
D'Abreton PC, Lindesay JA (1993) Water vapour transport over southern Africa during wet and dry early and late summer months. Int J Climatol 13:151-170

D'Abreton PC, Tyson PD (1995) Divergent and non-divergent water vapour transport over southern Africa during wet and dry conditions. Meteorol Atmos Phys 55:47-59

D'Abreton PC, Tyson PD (1996) Three-dimensional kinematic trajectory modelling of water vapour transport over southern Africa. Water SA 22:297-306

Harrison MSJ (1984) A general classification of South African summer rainfall bearing synoptic systems. J Climatol 4:547-560

Jury MR, Pathack B (1991) A study of weather and climate variability over the tropical southwest Indian Ocean. Meteorol Atmos Phys 47:37-48

Jury MR, Valentine HR, Lutjeharms JRE (1993) Influence of the Agulhas Current on summer rainfall on the southeast coast of South Africa. J Appl Meteorol 32:1282-1287

Kalnay E and 21 others (1996) The NCEP/NCAR 40-year reanalysis project. Bull Am Meteorol Soc 77:437-471

Liebmann B, Smith CA (1996) Description of a complete (interpolated) outgoing longwave radiation dataset. Bull Am Meteorol Soc 77:1275-1277

Lindesay JA (1988) South Africa rainfall, the Southern Oscillation and a Southern Hemisphere semi-annual cycle. J Climatol 8:17-30

Mason SJ (1995) Sea-surface temperature-South African rainfall associations, 1910-1989. Int J Climatol 15:119-135

Mason SJ, Jury MR (1997) Climate variability and change over southern Africa: a reflection on underlying processes. Prog Phys Geog 21:23-50

Reason CJC (1998) Warm and cold events in the southeast Atlantic/SWIO region and potential impacts on circulation and rainfall over southern Africa. Meteorol Atmos Phys 69:49-66

Reason CJC (2001) Subtropical Indian Ocean SST dipole events and southern African rainfall. Geophys Res Lett 28:2225-2227

Reason CJC, Mulenga H (1999) Relationships between South African rainfall and SST anomalies in the southwest Indian Ocean. Int J Climatol 19:1651-1673

Reason CJC, Rouault M (2002) ENSO-like decadal patterns and South African rainfall. Geophys Res Lett 29:10.1029/2002GL014663

Reason CJC, Allan RJ, Lindesay JA, Ansell TJ (2000) ENSO and climatic signals across the Indian Ocean Basin in the global context:part I, interannual composite patterns. Int J Climatol 20:1285-1327

Rouault M, White SA, Reason CJC, Lutjeharms JRE, Jobard I (2002) Ocean-atmosphere interaction in the Agulhas current region and a South African extreme weather event. Weather Forecast 17(4):655-669

Tennant W, Hewitson BC (2002) Intra-seasonal rainfall characteristics and their importance to the seasonal prediction problem. Int J Climatol 22:1033-1048

Todd M, Washington R (1998) Extreme daily rainfall in southern African and southwest Indian Ocean tropical-temperate links. S Afr J Sci 94:64-70

Tyson PD (1986) Climatic change and variability in southern Africa. Oxford University Press, Cape Town

Tyson PD, Preston-Whyte RA (2000) The weather and climate of southern Africa. Oxford University Press, Oxford

Walker ND (1990) Links between South African summer rainfall and temperature variability of the Agulhas and Benguela current systems. J Geophys Res B 95:3297-3319

Submitted: September 23, 2002; Accepted: February 23, 2004 Proofs received from author(s): April 2, 2004 